\title{
In-situ Enhancement of Soybean Straw Decomposition by Trichoderma viride and its Impact on the Soybean Crop Productivity and Economics
}

\author{
Pradnya Patre, M.R. Deshmukh, Arvind Kumar* and V.M. Bhale
}

Department of agronomy, Dr. Panjabrao Deshmukh Krishi Vidyapeeth, Akola, Maharashtra, India 444104

*Corresponding author

\section{A B S T R A C T}

\section{Keywords}

Soybean, Straw Decomposition, Tricoderma viride, Yield, Economics

Article Info

Accepted:

07 January 2019

Available Online:

10 February 2019
A field experiment was conducted in 2015-16 at Akola (MS) to find out the impacts of insitu enhanced straw decomposition on soybean yield and economics. It was laid into the Randomized Block design with 4 replications where 5 treatment combinations made for nutrient management through combining the inorganic fertilizer, straw application with and without Trichoderma viride application. The study revealed that Yield attributes, grain yield, straw yield, GMR and B:C ratio was significantly improved with application of RDF through chemical fertilizers. But, the application of $75 \% \mathrm{RDN}+25 \% \mathrm{~N}$ through soybean straw $+T$. viride also improved all parameters equally. So, it could be concluded that application of $75 \% \mathrm{RDN}+25 \% \mathrm{~N}$ through soybean straw $+T$. viride proved to be the most feasible system of integrated nutrient management and the application of decomposition enhancer, i.e. Trichoderma viride posses the potential to replace the source of nitrogen.

\section{Introduction}

Globally, The higher market value and post processing market of soybean gaining much attention of soybean grower as well as researchers. The limited availability of resources, land and intensive system of crop production are expecting maximum output / unit inputs. The continuous use of chemical inputs leads to serious nutrient imbalances and soil degradation. The integrated nutrient management and soil fertility challenges for sustainable agriculture promote the practice of organic agriculture, and introduction of the use of compost fungus activators in addition to organic fertilizer (Ponce, 2004) as substitute for chemical fertilizer in crop production by small farmers. On an average cereal, pulses and oilseed crop residues contain about $0.5 \% \mathrm{~N}, 0.2 \% \mathrm{P}_{2} \mathrm{O}_{5}$ and $1.5 \%$ $\mathrm{K}_{2} \mathrm{O}$. For judicious utilization of crop residues, Ex-situ composting requires adequate resources, land and labour and time consuming so farmers are not ready to adopting this technique while In-situ decomposition of crop residues provide great avenue for resolving the issue of residue management. The cellulolytic fungal species viz., Trichoderma has key role in biodegradation of agricultural residues (Gaur, 1999). It is employed widely in agriculture because it releases a variety of compounds 
that induce systemic resistance against soil borne pathogen (Harman, 2006), and enhances crop productivity through its great ability to decompose crop residues Hence its soil application may enhance the process of decomposition (Waghunde et al., 2016), and availability of nutrients especially nitrogen to the soil (Rudresh et al., 2005).

Keeping in view of above facts that the dual function of Trichoderma viride for enhancing the crop productivity and soil fertility it was worthwhile to plan and undertake an experiment entitled "In-situ enhancement of soybean straw decomposition by Trichoderma viride and its impact on the soybean crop productivity and economics".

\section{Materials and Methods}

A field experiment was conducted during the year 2015-16 at the Research Farm of Department of Agronomy, Dr. Panjabrao Deshmukh Krishi Vidyapeeth, Akola (Maharashtra). The soil of the experimental site was very fine, clayey dominated by smectite clay mineral which having swell shrink property. It was slightly alkaline in reaction, medium in organic carbon content, low in nitrogen and phosphate content while very high in exchangeable potassium. The rainfall received during the cropping period amounted to $557 \mathrm{~mm}$ as against the normal of $599.5 \mathrm{~mm}$ for the specific duration. However, the crop experienced two dry spells; first during the seedling stage; and second during the pod formation stage. The experiment was laid out in randomized block design with four replications. The Details of experimental treatments and their time of application are given in the Table 1 .

Plant Yield attributes such as Number of pods plant $^{-1}$, Weight of pods plant ${ }^{-1}(\mathrm{~g})$, Weight of grains plant ${ }^{-1}(\mathrm{~g})$, Grain yield $\left(\mathrm{kg} \mathrm{ha}^{-1}\right)$, Straw yield $\left(\mathrm{kg} \mathrm{ha}{ }^{-1}\right)$, Biological yield $\left(\mathrm{kg} \mathrm{ha}^{-1}\right)$,
Harvest index (Donald and Hamblin, 1976) and Test weight (g) were studied. In economics, Cost of cultivation ( $\mathrm{Rs} \mathrm{ha}{ }^{-1}$ ), Gross monetary return (Rs ha ${ }^{-1}$ ), Net monetary return (Rs ha ${ }^{-1}$ ) and Benefit cost ratio were calculated. The formulas were used as below:-

H.I. $(\%)=$ Grain yield $\left(\mathrm{kg} \mathrm{ha}^{-1}\right) /$ Biological yield $\left(\mathrm{kg} \mathrm{ha}^{-1}\right)$ x 100

Gross monetary returns $\left(\mathrm{Rs} \mathrm{ha}^{-1}\right)=$ total economic yield $(\mathrm{kg} / \mathrm{ha}) \times$ Price of commodity (Rs/kg)

Gross monetary returns ( $\mathrm{Rs} \mathrm{ha}^{-1}$ ) Benefit cost ratio $=$

Cost of cultivation $\left(\mathrm{Rs} \mathrm{ha}^{-1}\right)$

Experimental data were analyzed by adopting standard statistical methods of analysis of variance where critical difference kept at the $5 \%$ level of significance (Gomez and Gomez, 1984).

\section{Results and Discussion}

\section{Yield attributes of soybean}

The changes thus induced due to managerial involvement are precisely reflected in the yield attributes of the plant. Hence, any significant differences observed in the values of various yield attributes can directly be correlated with the treatment effects. The data obtained through it are presented in the Table 2.

\section{Number of pods plant ${ }^{-1}$ of soybean}

It is evident from the data presented in Table 2. Significantly highest number of pods plant $^{-1}$ (69.50) was noticed with treatment RDF alone. However, the values obtained with this treatment (62.78) were found statistically identical with that of treatment 
$75 \% \mathrm{RDN}+25 \% \mathrm{~N}$ thr. soy. straw $+T$. viride. The later treatment was also found at par with that of treatments $75 \% \mathrm{RDF}+25 \% \mathrm{~N}$ thr. soy. straw and $50 \% \mathrm{RDN}+50 \% \mathrm{~N}$ thr. soy. straw $+T$. viride with 58.18 and 55.95 pods plant ${ }^{-1}$, respectively. Significantly lowest number of pods (50.95) was recorded with treatment $50 \%$ RDN $+50 \% \mathrm{~N}$ thr. Soy. straw .

\section{Weight of pods plant ${ }^{-1}(\mathrm{~g})$ of soybean}

Weight of pods plant ${ }^{-1}$ was found to be significantly improved with treatments RDF alone $(21.38 \mathrm{~g})$ and $75 \% \mathrm{RDN}+25 \% \mathrm{~N}$ thr. soy. straw $+T$. viride, $(19.76 \mathrm{~g})$, both being at par with each other. However, the later treatment recorded statistically similar results with that of treatment $75 \% \mathrm{RDN}+25 \% \mathrm{~N}$ thr. soy. straw with the weight of pods plant ${ }^{-1}$ to the tune of $17.81 \mathrm{~g}$. Treatments T5 and T4, i.e. application of $50 \% \mathrm{RDN}+50 \% \mathrm{~N}$ thr. soy. straw with and without incorporation of $T$. viride did not improved the status of pod weight to a satisfactory level and thus produced significantly lowest pod weight of 15.85 and $14.90 \mathrm{~g}$, respectively.

\section{Weight of pods (g) plant ${ }^{-1}$ of soybean}

Mean weight of grains plant ${ }^{-1}$ of soybean was about 10.80 g. Application of $100 \%$ RDF through chemical fertilizers significantly improved the weight of pods plant $^{-1}$ of soybean. Among the replacement of nitrogen through soybean straw treatments, application of $75 \% \mathrm{RDN}+25 \% \mathrm{~N}$ thr.soy.straw $+T$. viride proved as the best treatment with weight of grains plant ${ }^{-1}$ up to $11.66 \mathrm{~g}$. The superiority of this treatment was also evident from the statistical analysis, which revealed its similarity with treatment $\mathrm{RDF}$ alone. Treatment $75 \%$ RDN $+25 \% \mathrm{~N}$ thr.soy.straw also yielded $10.94 \mathrm{~g}$ of grains being statistically similar with that of treatment T3.Among the treatments where $50 \%$ of $\mathrm{N}$ was replaced through soybean straw, the treatment where $T$. viride was not applied recorded significantly lowest weight of pods (9.26 g) plant ${ }^{-1}$.

\section{Test weight ( $g$ ) of soybean}

Significantly highest test weight (14.71 g) was recorded with treatment RDF alone, being statistically identical with that of treatments $75 \% \mathrm{RDN}+25 \% \mathrm{~N}$ thr. soy. straw $+T$. viride $(12.83 \mathrm{~g})$ and $75 \% \mathrm{RDN}+25 \% \mathrm{~N}$ thr. soy. straw $(12.56 \mathrm{~g})$. The remaining treatments recorded somewhat inferior values of test weight of soybean. Similar results supports the findings of Arjumand Banu et al., (2012), Konthoujam et al., (2013) and Haque et al., (2012) indicating that influences of bio fertilizer and chemical fertilizer on different levels (50- 100\% NPK) increases number of pods plant ${ }^{-1}$, weight of pods, grain pods $^{-1}$ in soybean.

\section{Crop yield studies}

The relevant data in respect of grain and straw yield as obtained during the course of investigation are presented in Table 3 .

\section{Seed yield $\left(\mathrm{kg} \mathrm{ha}^{-1}\right)$ of soybean}

As evident from the data presented in Table 3. The treatment where nutrients were supplied directly in the available form (i.e. chemical fertilizers at treatment RDF alone), recorded significantly highest seed yield $\left(2122 \mathrm{~kg} \mathrm{ha}^{-1}\right)$ of soybean. Among the treatments where partial addition of nitrogen was made through soybean straw, significantly highest crop yield (1919 $\mathrm{kg} \mathrm{ha}^{-1}$ ) was observed with treatment where $25 \%$ of $\mathrm{N}$ was added through soybean straw which was enriched later on with addition of $T$. viride. However, these two treatments i.e. RDF alone and $75 \% \mathrm{RDN}+$ $25 \% \mathrm{~N}$ thr.soy.straw $+T$. viride were found statistically identical with each other. The reduction in yield due to $25 \% \mathrm{~N}$ replacement 
through soybean straw + application of $T$. viride was up to 9.57 per cent over treatment RDF alone. The remaining nutrient management treatments through soybean straw were found to be at par among each other, however, the yield decrease with these treatments as compared to RDF alone was that of 13.86(T2), 17.44(T5) and 20.03 (T4) per cent. Numerically the lowest yield of $1697 \mathrm{~kg} \mathrm{ha}^{-1}$ was recorded with treatment 50 $\%$ RDN $+50 \% \mathrm{~N}$ thr. soy. straw (T4). Similar results were supporting the findings of Bharne (2003), Arjumand et al., (2012), Haque et al., (2012), Bhadoria et al., (2014) indicating that the Trichoderma-enriched biofertilizers combined with chemical $\mathrm{N}$ fertilizer significantly improves grain yield.

\section{Straw yield $\left(\mathrm{kg} \mathrm{ha}^{-1}\right)$ of soybean}

Significantly superior treatment (RDF alone) yielded the straw to an extent of $2809 \mathrm{~kg} \mathrm{ha}^{-1}$. It was followed by treatments $75 \% \mathrm{RDN}+$ $25 \% \mathrm{~N}$ thr.soy.straw $+T$. viride (T3) and $75 \%$ $\mathrm{RDN}+25 \% \mathrm{~N}$ thr.soy.straw (T2) with straw yield of 2609 and $2537 \mathrm{~kg} \mathrm{ha}^{-1}$, respectively. Lowest straw yield of $2347 \mathrm{~kg} \mathrm{ha}^{-1}$ was registered with treatment $50 \% \mathrm{RDN}+50 \% \mathrm{~N}$ thr.soy.straw (T4). Similar results were supporting the findings of Arjumand et al., (2012), Haque et al., (2012), Bhadoria et al., (2014) indicating that the Trichodermaenriched biofertilizers combined with chemical $\mathrm{N}$ fertilizer significantly improves seed yield in crops.

\section{Biological yield $\left(\mathrm{kg} \mathrm{ha}^{-1}\right)$ of soybean}

Significant improvement in biological yield was observed with treatment RDF alone. This treatment yielded to the tune of $4931 \mathrm{~kg} \mathrm{ha}^{-1}$ and superseded remaining $\mathrm{N}$ management treatments, indicating quick and assured availability of nutrients at the respective critical crop growth stages. Among the residue management treatments, T3 (75\%
$\mathrm{RDN}+25 \% \mathrm{~N}$ thr. soy. straw $+T$. viride) was found as the most promising treatment, which recorded $4528 \mathrm{~kg} \mathrm{ha}^{-1}$ of biological yield and proved superior over remaining residue management treatments. Similar results were supporting the findings of Bharne (2003), Arjumand et al., (2012), Haque et al., (2012), Bhadoria et al., (2014) indicating that the Trichoderma-enriched biofertilizers combined with chemical $\mathrm{N}$ fertilizer significantly improves the economic and biological yields in crops.

\section{Harvest index of soybean}

The relevant data in respect of biological yield and harvest index as obtained from the present investigation are placed at Table 3.

It is obvious that, the maximum harvest index of 43.03 was evident with treatment RDF alone. The next best treatment in this regard was that of (T3) with respective value of 42.38. Lowest harvest index of 41.96 was noted with treatment T4 (50\% RDN $+50 \% \mathrm{~N}$ thr. soy. straw). Remaining treatments were found to be intermediate in their performance of harvest index. Similar results were supporting the findings of Arjumand et al., (2012), Haque et al., (2012), Bhadoria et al., (2014) indicating that the Trichodermaenriched biofertilizers combined with chemical $\mathrm{N}$ fertilizer significantly improves the harvest index.

\section{Economic studies}

Sustainability of agricultural system ensures when penultimate aim of economic security is achieved apart from that of environmental keep up. Thus in order to test the feasibility of different nutritional treatments under study, the economic analysis was undertaken after the completion of all agricultural operations and its marketing. The economic studies are presented in Table 4. 


\section{Cost of cultivation (Rs ha $\left.{ }^{-1}\right)$}

As such in present investigation, the input cost incurred towards cultivating soybean crop as influenced by different nutrient management treatments has been studied and the relevant data obtained are presented in Table 4.

It could be observed from the data that the cost of cultivation increased due to addition of soybean straw and application of $T$. viride in treatments where RDF was replaced to some extent with soybean straw. Treatment T1 (RDF Alone) recorded the cost of cultivation of 28380 Rs. ha ${ }^{-1}$. Increase in cost of cultivation with $25 \%$ replacement of RDN through soybean straw was to the tune of 8 to10 per cent with treatments $\mathrm{T} 2(75 \% \mathrm{RDN}$ $+25 \% \mathrm{~N}$ thr. soy. straw and T3 (75\% RDN + $25 \% \mathrm{~N}$ thr. soy. straw $+T$. viride, with the respective cost of 30743 and $31141 \mathrm{Rs} \mathrm{ha}^{-1}$, respectively. While, it increased by about 17 to 20 per cent when the RDN was replaced with soybean straw to the tune of $50 \%$ as in case of treatments $\mathrm{T} 4(50 \% \mathrm{RDN}+50 \% \mathrm{~N}$ thr. soy. straw) (33300 Rs ha ${ }^{-1}$ ) and T5 (50\% $\mathrm{RDN}+50 \% \mathrm{~N}$ thr. soy. straw $+T$. viride) (34108 Rs ha ${ }^{-1}$ ). Though the cost of cultivation did increase due to addition of crop residues in the field, still its feasibility and non monetary benefits are much greater when sustainable practice of addition of crop residue is done, especially when our aim is to conserve the natural resources and to make agricultural business much resilient.

Table.1 Details of experimental treatments

\begin{tabular}{|l|l|l|}
\hline Treatment & \multicolumn{1}{|c|}{ Treatment Details } & $\begin{array}{l}\text { Time of } \\
\text { application }\end{array}$ \\
\hline $\mathbf{T}_{\mathbf{1}}$ & RDF- 30:75:30 kg NPK ha & At sowing \\
\hline $\mathbf{T}_{\mathbf{2}}$ & $75 \% \mathrm{RDN}+25 \% \mathrm{~N}$ through soybean straw & Before sowing \\
\hline $\mathbf{T}_{\mathbf{3}}$ & $75 \% \mathrm{RDN}+25 \% \mathrm{~N}$ through soybean straw + T. viride & Before sowing \\
\hline $\mathbf{T}_{\mathbf{4}}$ & $50 \% \mathrm{RDN}+50 \% \mathrm{~N}$ through soybean straw & Before sowing \\
\hline $\mathbf{T}_{\mathbf{5}}$ & $50 \% \mathrm{RDN}+50 \% \mathrm{~N}$ through soybean straw $+\mathrm{T}$.viride & Before sowing \\
\hline
\end{tabular}

Table.2 Yield attributes plant ${ }^{-1}$ of soybean as influenced by various treatments

\begin{tabular}{|c|c|c|c|c|}
\hline \multirow[t]{2}{*}{ Treatments } & \multicolumn{4}{|c|}{ Yield attributes plant $^{-1}$} \\
\hline & $\begin{array}{l}\text { Number } \\
\text { of pods } \\
\text { plant }^{-1}\end{array}$ & $\begin{array}{l}\text { Weight of } \\
\text { pods } \\
\text { plant }^{-1}(\mathrm{~g})\end{array}$ & $\begin{array}{l}\text { Weight of } \\
\text { grains plant } \\
\text { (g) }\end{array}$ & $\begin{array}{l}\text { Test } \\
\text { weight } \\
\text { (g) }\end{array}$ \\
\hline T1 (RDF- 30:75:30 kg NPK ha") & 69.50 & 21.38 & 12.20 & 14.71 \\
\hline T2 (75\% RDN + 25\% N thr. soy. straw & 58.18 & 17.81 & 10.94 & 12.56 \\
\hline T3 (75\% RDN + 25\% N thr. soy.straw + T. viride & 62.78 & 19.76 & 11.66 & 12.83 \\
\hline T4 (50\% RDN + 50\% N thr. soy. straw & 50.95 & 14.90 & 9.26 & 11.85 \\
\hline T5 (50\% RDN + 50\% N thr. soy. straw + T.viride & 55.95 & 15.85 & 9.95 & 12.39 \\
\hline $\operatorname{SE}(\mathbf{m}) \pm$ & 3.348 & 1.156 & 0.407 & 0.772 \\
\hline CD at $5 \%$ & 10.243 & 3.524 & 1.235 & 2.352 \\
\hline GM & 59.47 & 17.94 & 10.80 & 12.87 \\
\hline
\end{tabular}

* thr. soy. - through soybean 
Table.3 Seed yield $\left(\mathrm{kg} \mathrm{ha}^{-1}\right)$, straw yield $\left(\mathrm{kg} \mathrm{ha}^{-1}\right)$, biological yield $\left(\mathrm{kg} \mathrm{ha}^{-1}\right)$ and harvest index of soybean as influenced by various treatments

\begin{tabular}{|c|c|c|c|c|}
\hline Treatments & $\begin{array}{l}\text { Seed yield } \\
\left(\mathrm{kg} \mathrm{ha}^{-1}\right)\end{array}$ & $\begin{array}{l}\text { Straw } \\
\text { yield }\end{array}$ & Treatments & $\begin{array}{l}\text { Seed yield } \\
\left(\mathrm{kg} \mathrm{ha}^{-1}\right)\end{array}$ \\
\hline T1 (RDF- 30:75:30 kg NPK ha ${ }^{-1}$ ) & 2122 & 2809 & 4931 & 43.03 \\
\hline T2 $(75 \%$ RDN + $25 \% \mathrm{~N}$ thr. soy. straw & 1828 & 2537 & 4365 & 41.88 \\
\hline T3 $(75 \%$ RDN + $25 \% \mathrm{~N}$ thr. soy. straw $+T$. viride & 1919 & 2609 & 4528 & 42.38 \\
\hline T4 (50\% RDN + 50\% N thr. soy. straw & 1697 & 2347 & 4044 & 41.96 \\
\hline T5 (50\% RDN + 50\% N thr. soy. straw + T.viride & 1752 & 2391 & 4143 & 42.29 \\
\hline $\mathrm{SE}(\mathrm{m}) \pm$ & 45.315 & 55.130 & 104.661 & 0.320 \\
\hline CD at $5 \%$ & 138.423 & 166.312 & 317.281 & 0.954 \\
\hline GM & 1864 & 2539 & 4402 & 42.31 \\
\hline
\end{tabular}

Table.4 Cost of cultivation (COC), Gross monetary returns (GMR), Net monetary returns (NMR), and Benefit:Cost $(\mathrm{B}: \mathrm{C})$ ratio of soybean as influenced by various treatments

\begin{tabular}{|l|l|l|l|}
\hline Treatments & $\begin{array}{l}\text { COC } \\
\left.\text { Rs ha }^{-1}\right)\end{array}$ & $\begin{array}{l}\text { Treatments } \\
\left.\text { Rs ha }^{-1}\right)\end{array}$ & B:C Ratio \\
\hline T1 (RDF- 30:75:30 kg NPK ha ${ }^{-1}$ ) & 28380 & 76362 & 2.69 \\
\hline T2 (75\% RDN + 25\% N thr. soy. straw & 30743 & 65958 & 2.15 \\
\hline T3 (75\% RDN + 25\% N thr. soy. straw + T. viride & 31141 & 69158 & 2.22 \\
\hline T4 (50\% RDN + 50\% N thr. soy. straw & 33300 & 61219 & 1.84 \\
\hline T5 (50\% RDN + 50\% N thr. soy. straw + T. viride & 34108 & 63155 & 1.85 \\
\hline SE(m)+ & -- & 3280 & -- \\
\hline CD at 5\% & -- & 10027 & -- \\
\hline GM & 31534 & 67170 & 2.15 \\
\hline
\end{tabular}

\section{Gross monetary returns ( $\left.\mathrm{Rs} \mathrm{ha}^{-1}\right)$}

Average gross monetary return (GMR) obtained from the present investigation was that of $67170 \mathrm{Rs} \mathrm{ha}^{-1}$ and Data presented in Table 4.

Significantly highest GMR (76362 $\left.\mathrm{Rs} \mathrm{ha}^{-1}\right)$ was recorded with treatment $\mathrm{T} 1$ (RDF alone). It was followed by other residue management treatments in the decreasing order of treatments $\mathrm{T} 3>\mathrm{T} 2>\mathrm{T} 5>\mathrm{T} 4$, with respective GMR values of 69158, 65958, 63155 and $61219 \mathrm{Rs} \mathrm{ha}^{-1}$. The resultant increase in GMR with treatment was due to increased production of soybean with it. While, the other crop residue addition treatments could not reach to that level due to its increased cost of cultivation and comparatively lower crop yields.

\section{Benefit to cost ratio}

Benefit to cost ratio gives an appropriate indication of net benefit per rupee investment which presented in Table 4.

Highest benefit to cost ratio of 2.69 was obtained with treatment, where RDF was applied through chemical fertilizers (T1). The next best treatment in this respect was treatment $\mathrm{T} 3$, where $25 \% \mathrm{~N}$ was replaced 
through application of soybean straw in combination with Trichoderma viride, by providing the benefit to cost ratio of 2.22. Treatment T2, where $25 \% \mathrm{~N}$ was given through soybean straw without addition of $T$. viride also responded well and resulted in providing $\mathrm{B}: \mathrm{C}$ ratio of 2.15 . The nutrient management treatments where $50 \% \mathrm{~N}$ was replaced through soybean straw with or without application of $T$. viride did not perform to a level of significance with B:C ratio of 1.85 and 1.84 , respectively.

It could be concluded that application of $75 \%$ $\mathrm{RDN}+25 \% \mathrm{~N}$ thr. soy. straw $+T$. viride proved to be the most feasible system of integrated nutrient management, which can significantly improved the crop performance i.e. Yield attributes, grain yield, straw yield, GMR, NMR and B:C ratio.

Further, the system of in-situ decomposition of crop residue with application of decomposition enhancer, i.e. Trichoderma viride also established its feasibility under field condition, as it posses the potential to replace the source of nitrogen.

Thus, in nutshell, the economic results discussed above indicate the feasibility of replacing at least $25 \%$ nitrogen through field application of soybean straw in combination with Trichoderma viride as decomposition enhancer.

\section{References}

Arjumand Banu S. S., N. B. Nag, Neethu Patil, E. T. Puttaiah, (2012) Growth and yield of soybean as influence by biofertilizer and chemical fertilizer. International J. of Life Sci., 1(4): 108110.

Bhadoria, R., R. V. Singh, S. P. Singh, and Arun Kumar, (2014) Effect of Trichoderma sp.on growth, yield and quality of sugarcane. Indian J. Agrica. 3: $19-22$.

Bharne, V. V., C. S. Choudhary, S. T. Dangore, P. D. Raut, P. D. Thakre, (2003) Studies on effect of decomposition of various crop residues and quality parameters of summer mung. Anls Plant Physio. 17 (2): 125129.

Donald, C.M. and Hamblin, J. (1976) The Biological Yield and Harvest Index of Cereals as Agronomic and Plant Breeding Criteria. Advan. Agron. 28: 361-405.

Gaur, A.C., (1999) Microbial Technology for Composting of Agricultural Residues by Improved Methods. Indian Council of Agricultural Research, New Delhi.

Gomez, A.A., A.K. Gomez, (1984) Statistical Procedures for Agricultural Research. A Wiley Inster Science Publication, New Work. Pp. 241-262.

Haque, M. M., G. N., Ilias, and A. H. Molla, (2012). Impact of Trichodermaenriched Biofertilizer on the Growth and Yield of Mustard (Brassica rapa L.) and Tomato (Solanum lycopersicon Mill.). Scien J. Krishi Found., The Agriculturists 10(2): 109-119.

Harman, G.E., (2006) Overview of mechanisms and uses of Trichoderma spp. Phytopatho. 96:190-194.

Konthoujam, N. D; Tensubam, B. S; Athokpam, H.S; Naorem, B.S. and Diana Shamurailatpam, (2013) Influence of inorganic, biological and organic manures on nodulation and yield of soybean (Glycine max L. Merrill) and soil properties. Australian J. Crop Sci. 7(9): 1407-1415.

Ponce, E.R., (2004) Special Issues in Agriculture. Philippine Institute for Development Studies and Bureau of Agricultural Research, Makati City, Philippines. Pp. 774.

Rudresh, D.L., Shivaprakash, M.K. and 
Prasad, R.D. (2005) Effect of combined application of Rhizobium, phosphate solubilizing bacterium and Trichoderma spp. on growth, nutrient uptake and yield of chickpea (Cicer aritenium L.). Appl. Soil Ecol, 28: 139-146.
Waghunde, R. R., Rahul, M. S., \& Ambalal, N. S., (2016) Trichoderma: A significant fungus for agriculture and environment. African J. Agri. Re. 11(22), 1952-1965.

\section{How to cite this article:}

Pradnya Patre, M.R. Deshmukh, Arvind Kumar and Bhale, V.M. 2019. In-situ Enhancement of Soybean Straw Decomposition by Trichoderma viride and its Impact on the Soybean Crop Productivity and Economics. Int.J.Curr.Microbiol.App.Sci. 8(02): 677-684. doi: https://doi.org/10.20546/ijcmas.2019.802.077 